\title{
Evaluation of 25-hydroxy vitamin D levels in COVID-19 positive patients
}

\author{
(D)Harun Düğeroğlu \\ Ordu University Faculty of Medicine, Training and Research Hospital, Department of Internal Medicine, Ordu, Turkey
}

Cite this article as: Düğeroğlu H. Evaluation of 25-hydroxy vitamin D levels in COVID-19 positive patients. J Health Sci Med 2021; 4(6): 931-935.

\begin{abstract}
Aim: With this study, the aim was to evaluate the serum 25-hydroxy vitamin D levels in COVID-19 positive patients.

Material and Method: The study retrospectively screened the archive records for patient data from 732 patients, attending the pandemic clinic in our hospital from March 2020 to February 2021 aged over 18 years with COVID-19 positivity and serum 25-hydroxy vitamin D levels examined, with data from 360 control patients between the same dates in similar age group and without COVID-19 positivity. COVID-19 positive patients and control group patients were divided into three groups according to serum 25-hydroxy vitamin D levels (deficiency, insufficiency, and normal level).

Results: Of the 732 COVID-19 positive patients included in the study, 66.4\% were female ( $\mathrm{n}=486)$ and $33.6 \%$ were male $(\mathrm{n}=246)$. The mean serum $25(\mathrm{OH}) \mathrm{D}$ level in the COVID-19 positive patient group was calculated as $14.2 \pm 11.7 \mathrm{ng} / \mathrm{ml}$. For the 360 patients included in the COVID-19 negative control group, $70 \%$ were female $(n=252)$ and $30 \%$ were male ( $n=108)$. Mean serum $25(\mathrm{OH}) \mathrm{D}$ level in the COVID-19 negative control group was $27.6 \pm 12.1 \mathrm{ng} / \mathrm{l}$. There was a significant difference between the groups $(\mathrm{p}=0.012)$.

Conclusion: High rates of vitamin D deficiency and insufficiency are seen in COVID-19 positive patients. Sufficient levels of replacement for patients with low vitamin D levels will provide significant reductions in musculoskeletal system symptoms and complaints of patients. We think vitamin D is a protective vitamin for COVID-19.
\end{abstract}

Keywords: COVID-19, pandemic, 25-hydroxy vitamin D, prognosis

\section{INTRODUCTION}

The coronavirus family is a positive strand RNA virus family which is responsible for $5-10 \%$ of all acute upper respiratory tract infections in adults (1). Research after reports of viral pneumonia cases in Wuhan city in China in December 2019 identified a new coronavirus vector. Initially called '2019-nCoV' the virus was later called 'SARS-CoV-2' due to similarity to the virus causing severe acute respiratory syndrome (SARS). The disease spread rapidly around the world and a pandemic was declared by the World Health Organization in March 2020 (2). 'Coronavirus disease 2019 (COVID-19)', causing a broad clinical spectrum from asymptomatic cases to cases with acute severe respiratory distress requiring intensive care, has infected many people since December 2019 to date and caused the death of many people (3).

Patients with SARS-CoV-2 infection generally have mild clinical progression, but may also develop severe complications resulting in mortality $(4,5)$. Among the risk factors for severe COVID-19 infection are advanced age, obesity, smoking habit, chronic renal failure, and comorbid diseases like chronic lung disease, chronic liver disease, cardiovascular diseases, hypertension, malignancy and diabetes mellitus $(6,7)$. As most of these risk factors are preventable and controllable diseases, they are important to lessen the severity of COVID-19. A study by Dong et al. (8) assessed 731 COVID-19 positive patients with 1412 COVID-19 suspected cases. They identified that more than $90 \%$ of cases were asymptomatic, mild or moderately symptomatic cases.

Vitamin D is a steroid with hormone-like functions playing a role in bone growth and mineral metabolism (9). At the same time, vitamin D has a direct effect on calcium and phosphorus metabolism (10). Vitamin $\mathrm{D}$ receptors were identified in many tissues and this situation shows that vitamin $\mathrm{D}$ deficiency plays a role in many diseases (11). 
Currently, vitamin D deficiency and insufficiency are important problems and are thought to play a role in the etiology of many chronic diseases (12). In many studies, vitamin $\mathrm{D}$ insufficiency was shown to be associated with viral and bacterial infections, cardiovascular diseases, multiple sclerosis, psychiatric disorders like depression, diabetes and autoimmune diseases and even breast and colon cancer (13-16). Patients with chronic disease who do not receive sufficient amounts of vitamin $\mathrm{D}$ in foods or who have disrupted vitamin $\mathrm{D}$ metabolism due to the chronic disease process may have vitamin D deficiency. Additionally, medications used for chronic diseases may disrupt vitamin D metabolism. Some studies showed that vitamin $\mathrm{D}$ deficiency in patients with chronic disease may shorten the life expectancy of the patient and increase mortality and cause severe complications (17). They proposed that the reason for this in situations with vitamin $\mathrm{D}$ insufficiency is due to the loss of the positive effects of vitamin $\mathrm{D}$ in the body of anti-inflammatory, antioxidant and anti-ischemic properties (18).

Serum 25-hydroxy vitamin D (25(OH)D) measurements are a test used to show vitamin $\mathrm{D}$ levels of individuals. Serum 25(OH)D levels below $20 \mathrm{ng} / \mathrm{mL}$ are vitamin $\mathrm{D}$ deficiency, 21-30 $\mathrm{ng} / \mathrm{mL}$ are vitamin D insufficiency and levels above $30 \mathrm{ng} / \mathrm{mL}$ are accepted as normal vitamin $\mathrm{D}$ levels (19). Low 25(OH)D levels may cause widespread body pain, muscle and skeletal weakness, bone fractures and bone mineralization inadequacy in patients $(20,21)$.

There are several studies showing the protective effects of vitamin D against community-acquired pneumonia, interstitial pneumonia and influenza A infections. Again, these studies showed regulatory effects on monocyte activation and IL- 6 in the cytokine storm $(22,23)$. Several other studies showed the active form of vitamin $\mathrm{D}$ of $1,25(\mathrm{OH}) 2 \mathrm{D} 3$ increased ACE2 expression in the lungs and had positive effects on lung injury $(24,25)$.

Cytokine storm is a significant problem in COVID-19 patients. It is possible to lessen the severity of disease by keeping vitamin $\mathrm{D}$ at normal levels to reduce the synthesis of proinflammatory cytokines in COVID-19 patients (26). A study by Ilie et al. (27) identified a negative correlation between mean vitamin D levels of patients and COVID-19 case numbers in some European countries.

With this study, the aim was to evaluate the serum 25-hydroxy vitamin D levels in COVID-19 positive patients.

\section{MATERIAL AND METHOD}

This study was approved by Ordu University, Clinical Research and Ethics Committee (Date: 15/04/2021, Decision No: 93). All procedures were carried out in accordance with the ethical rules and the principles of the Declaration of Helsinki.
The study retrospectively screened archive records of 732 patients, aged over 18 years with COVID-19 positivity attending the pandemic clinic in our hospital from March 2020 to February 2021, with 360 patients without COVID-19 positivity comprising normal individuals in a similar age group between the same dates. Patient data (age, gender, serum 25(OH)D levels) were retrospectively obtained from file records. Our study did not include patients receiving vitamin $\mathrm{D}$ and immunosuppressive medication treatment, with bone metabolism diseases, with cancer, pregnant or breastfeeding patients, with osteoporosis and osteomalacia diagnosis, with primary hyperparathyroidism, with chronic renal failure, patients who drank alcohol or smoked and with inadequate or missing records. Our hospital studied serum $25(\mathrm{OH}) \mathrm{D}$ levels with an Abbott Architecture i2000-SR autoanalyzer. Patients with serum 25(OH)D levels below $20 \mathrm{ng} / \mathrm{mL}$ were placed in the vitamin $\mathrm{D}$ deficiency group, those with 21-30 $\mathrm{ng} / \mathrm{mL}$ were in the vitamin $\mathrm{D}$ insufficiency group and patients with values above $30 \mathrm{ng} / \mathrm{mL}$ were included in the normal vitamin D group. Groups were analyzed for the presence of statistically significant differences. Additionally, data for the COVID-19 positive patient group were compared with data for the COVID-19 negative control group. Vitamin D levels of COVID-19 positive patients were examined in age groups. Serum $25(\mathrm{OH}) \mathrm{D}$ levels of patients were statistically assessed according to age group.

\section{Statistical Analysis}

All data were uploaded to IBM SPSS Statistics 22.0 (SPSS Inc., Chicago, Illinois) program. For assessment of data, number, percentage, mean and standard deviation were used as descriptive statistics. Distribution of data was assessed with the Kolmogorov-Smirnov test. Comparisons of groups used the student $\mathrm{T}$ test. Correlation analyses used the Pearson and Spearman tests. P values smaller than 0.05 were accepted as significant.

\section{RESULTS}

Of the 732 COVID-19 positive patients included in the study, $66.4 \%$ were women $(\mathrm{n}=486)$ and $33.6 \%(\mathrm{n}=246)$ were men. Mean age of patients was $45.2 \pm 11.9$ years (men $47.7 \pm 10.4$ years, women $46.5 \pm 10.1$ years). The mean serum $25(\mathrm{OH}) \mathrm{S}$ levels in the COVID-19 positive patient group were $14.2 \pm 11.7 \mathrm{ng} / \mathrm{mL}$. For the 360 patients included in the COVID-19 negative control group, 70\% were women $(n=252)$ and $30 \%$ were men $(n=108)$. The mean age of controls was $45.8 \pm 10.6$ years (men $44.5 \pm 11.4$ years, women $46.6 \pm 12.7$ years). The mean serum $25(\mathrm{OH})$ Dlevels for the COVID-19 negative control group patients were $27.6 \pm 12.1 \mathrm{ng} / \mathrm{mL}$. When statistical comparison was made between gender and serum $25(\mathrm{OH}) \mathrm{D}$ levels in the COVID-19 positive patient group and COVID-19 
negative control group patients, there was a significant difference between the groups $(\mathrm{p}=0.012)$ (Table 1).

\begin{tabular}{|c|c|c|c|c|c|}
\hline \multirow{3}{*}{$\begin{array}{l}\text { Serum } \\
25(\mathrm{OH}) \mathrm{D} \\
\text { levels }\end{array}$} & \multicolumn{2}{|c|}{$\begin{array}{l}\text { COVID-19 positive } \\
\text { patient group } \\
(n=732)\end{array}$} & \multicolumn{2}{|c|}{$\begin{array}{c}\text { COVID-19 } \\
\text { negative control } \\
\text { group }(n=360)\end{array}$} & \multirow{3}{*}{$\begin{array}{c}P \\
\text { value }\end{array}$} \\
\hline & $\begin{array}{c}\text { Female } \\
(n=486)\end{array}$ & $\begin{array}{c}\text { Male } \\
(n=246)\end{array}$ & $\begin{array}{r}\text { Female } \\
(n=252)\end{array}$ & $\begin{array}{c}\text { Male } \\
(n=108)\end{array}$ & \\
\hline & $\mathbf{n} / \%$ & $n / \%$ & $n / \%$ & $n / \%$ & \\
\hline $\begin{array}{l}\text { Deficiency } \\
(<20 \mathrm{ng} / \mathrm{ml})\end{array}$ & $234 / 48.2$ & $138 / 56.2$ & $69 / 27.3$ & $18 / 16.7$ & \multirow{3}{*}{0.012} \\
\hline $\begin{array}{l}\text { Insufficiency } \\
(21-30 \mathrm{ng} / \mathrm{ml})\end{array}$ & $141 / 29.0$ & $72 / 29.2$ & $96 / 38.1$ & $42 / 38.8$ & \\
\hline $\begin{array}{l}\text { Normal } \\
(>30 \mathrm{ng} / \mathrm{ml})\end{array}$ & $111 / 22.8$ & $36 / 14.6$ & $87 / 34.5$ & $48 / 44.5$ & \\
\hline
\end{tabular}

Additionally, COVID-19 positive patients were divided into age groups and serum 25(OH)D levels were assessed according to age group (Table 2). The serum $25(\mathrm{OH}) \mathrm{D}$ level was identified to be lowest in the 51-65-year age interval.

\begin{tabular}{|c|c|c|}
\hline $\begin{array}{c}\text { Age interval } \\
\text { (year) }\end{array}$ & $\begin{array}{c}\text { Mean serum } 25(\mathrm{OH}) \\
\text { D level }(\mathrm{ng} / \mathrm{ml})\end{array}$ & $\begin{array}{l}\text { Patient number and } \\
\text { percentage } n(\%)\end{array}$ \\
\hline $18-35$ & $17.70 \pm 13.04$ & $138(18.9)$ \\
\hline $36-50$ & $16.78 \pm 17.42$ & $213(29.1)$ \\
\hline $51-65$ & $12.36 \pm 11.01$ & $240(32.8)$ \\
\hline$>66$ & $13.45 \pm 10.21$ & $141(19.2)$ \\
\hline
\end{tabular}

\section{DISCUSSION}

The correlation between vitamin D levels and viral infections was reported in some studies. A study in India identified that after 6-months follow-up, patients with vitamin $\mathrm{D}$ deficiency had more upper respiratory tract infections compared to normal healthy individuals (28). The majority of these upper respiratory tract infections comprised viral infections. Among these, the most frequent vectors are rhinovirus, coronavirus, respiratory syncytial virus (RSV), adenovirus, influenza and parainfluenza. A study by Banajeh et al. (29) identified that vitamin $\mathrm{D}$ deficiency in patients with upper respiratory tract infections was associated with reduced neutrophil counts in circulation and hypoxemia. A study by Yao et al. (30) reported H7N9 pneumonia in two patients with advanced degree of vitamin $\mathrm{D}$ deficiency. In our study, $50.8 \%$ of COVID-19 positive patients had vitamin D deficiency, 29\% had vitamin D insufficiency and 20.2\% had normal vitamin D levels. Generally, vitamin D levels were identified to be lower in the COVID-19 positive patient group compared to the COVID-19 negative control group. Among the COVID-19 positive patients,
34 required respiratory support. The vitamin $\mathrm{D}$ levels of these patients were severely low and below $3 \mathrm{ng} / \mathrm{mL}$. Our small-scale study results show that COVID-19 patients have vitamin D deficiency; however, there is a need for more studies including higher patient numbers.

Though there are several studies assessing the relationship between vitamin $\mathrm{D}$ deficiency and infections, studies in recent times researched the protective effect of vitamin D supplementation on infections. For this reason, administering sufficient amounts of vitamin $\mathrm{D}$ supplementation to patients with low vitamin $\mathrm{D}$ levels is thought to provide a protective effect against infections (31). For this reason, we think that vitamin D replacement at appropriate doses for patients with vitamin D deficiency identified will be protective against several other infections, led by COVID-19 infection. However, a study by Arihiro et al. (32) showed that in spite of the significantly low incidence of upper respiratory tract infections in the patient group with vitamin D deficiency, there was no difference in influenza incidence. Urashima et al. (33) reported that vitamin $\mathrm{D}$ support in the winter months may reduce influenza A incidence. Similarly, a study by Camargo et al. (34) showed vitamin D supplementation significantly reduced acute respiratory tract infection risk in patients with vitamin D deficiency. In our study, we began oral vitamin $\mathrm{D}$ supplementation at appropriate doses for patients who were COVID-19 positive and with vitamin D deficiency/insufficiency identified.

To date, a variety of studies were performed researching vitamin $\mathrm{D}$ levels in healthy children and adults in Turkey. A study by Uçar et al. (35) identified $51.8 \%$ vitamin $\mathrm{D}$ deficiency and $20.7 \%$ vitamin D insufficiency. Erol et al. (36) found $25(\mathrm{OH}) \mathrm{D}$ levels were $10.6 \pm 6.5 \mathrm{ng} / \mathrm{mL}$ and $92.2 \%$ of patients had vitamin D levels below $20 \mathrm{ng} / \mathrm{mL}$. In our study, mean serum $25(\mathrm{OH}) \mathrm{D}$ levels were $14.2 \pm 11.7$ $\mathrm{ng} / \mathrm{mL}$ in COVID-19 positive patients, and $50.8 \%$ of patients had vitamin D levels below $20 \mathrm{ng} / \mathrm{mL}$ (vitamin D deficient), $29 \%$ had vitamin $\mathrm{D}$ levels from $21-30 \mathrm{ng} / \mathrm{mL}$ (vitamin D insufficient) and $20.2 \%$ had normal vitamin D levels (>30 ng/mL). In Turkey, inadequate nutrition, lifestyle variations and environmental factors play roles among reasons for the low vitamin $\mathrm{D}$ levels.

A review by Silva and Furlanetto (37) proposed the need to carefully assess reductions in $25(\mathrm{OH}) \mathrm{D}$ measured during the acute phase response. If vitamin $\mathrm{D}$ acts like a negative acute phase reactant, vitamin $\mathrm{D}$ supplementation will not provide any benefit. However, we think there is a need for more studies to strengthen this view. Ebadi and Montano-Loza (38) proposed the need to measure vitamin D levels in COVID-19 patients in their article, and recommended 50,000 IU vitamin D supplementation (total 100,000 IU) twice per week at time of diagnosis for patients with vitamin D below $20 \mathrm{ng} / \mathrm{mL}$. 


\section{CONCLUSION}

Vitamin D deficiency and insufficiency are observed at high rates in COVID-19 positive patients. For this reason, sufficient levels of replacement for patients with low vitamin $\mathrm{D}$ levels will provide clear reductions in musculoskeletal system symptoms and complaints. Additionally, vitamin $\mathrm{D}$ was shown to be a significant determinant of mortality due to antiinflammatory, antioxidant and antiischemic properties. For this reason, we think vitamin $\mathrm{D}$ is a protective vitamin for COVID-19

\section{ETHICAL DECLARATIONS}

Ethics Committee Approval: This study was approved by Ordu University, Clinical Research and Ethics Committee (Date: 15/04/2021, Decision No: 93).

Informed Consent: Because the study was designed retrospectively, no written informed consent form was obtained from patients.

Referee Evaluation Process: Externally peer-reviewed.

Conflict of Interest Statement: The authors have no conflicts of interest to declare.

Financial Disclosure: The authors declared that this study has received no financial support.

Author Contributions: All of the authors declare that they have all participated in the design, execution, and analysis of the paper, and that they have approved the final version.

\section{REFERENCES}

1. Ozcelik F, Tanoglu A, Çıracı MZ, Ozcelik IK. Use of immune modulator interferon-gamma to support combating COVID-19 pandemic. Int J Coronaviruses 2020; 1: 1-15.

2. World Health Organization (WHO). Coronavirus disease 2019 ( COVID-19): situation report - 61. March 20, 2020. Geneva: World Health Organization Geneva; 2020. Available from: https:// www.who.int/docs/default-source/coronaviruse/situationreports/20200321-sitrep-61-covid-19.pdf?sfvrsn=ce5ca11c_2. Accessed in 2021 (Jun 16).

3. COVID-19 Dashboard by the Center for Systems Science and Engineering (CSSE) at Johns Hopkins University(JHU). Available from: https://coronavirus.jhu.edu/map.html.

4. Jiehao C, Jin X, Daojiong L, et al. A case series of children with 2019 novel coronavirus infection: clinical and epidemiological features. Clin Infect Dis 2020; 71: 1547-51.

5. Liu W, Zhang Q, Chen J, et al. Detection of COVID-19 in Children in Early January 2020 in Wuhan, China. N Engl J Med 2020; 382: 1370-1.

6. Zhou F, Yu T, Du R, et al. Clinical course and risk factors for mortality of adult inpatients with COVID-19 in Wuhan, China: a retrospective cohort study. Lancet 2020; 395: 1054-62.

7. CDC COVID-19 Response Team. Preliminary estimates of the prevalence of selected underlying health conditions among patients with Coronavirus disease 2019-United States, February 12-March 28, 2020. MMWR Morb Mortal Wkly Rep 2020; 69: $382-6$
8. Dong Y, Mo X, Hu Y, et al. Epidemiological characteristics of 2143 pediatric patients with 2019 coronavirus disease in China. Pediatrics 2020: e20200702.

9. Bhatty SA, Shaikh NA, Irfan M, Kashif SM, Vaswani AS, Sumbhai A, Gunpat. Vitamin D deficiency in fibromyalgia. J Pak Med Assoc 2010; 60: 949-51.

10. Binkley N, Ramamurthy R, Krueger D. Low vitamin D status: definition, prevalence, consequences, and correction. Endocrinol Metab Clin North Am 2010; 39: 287-contents.

11. Wolfe F, Smythe HA, Yunus MB, et al. The American College of Rheumatology 1990 criteria for the classification of fibromyalgia. Arthritis Rheum 1990; 33: 160-72.

12. Altındağ O, Ögüut E, Gür A, Gürsoy S, Günay M. Serum vitamin D level and its relation with clinical parameters in fibromyalgia as a neuropathic pain. Orthop Muscular Syst 2014; 3: 171.

13. Cannell JJ, Vieth R, Umhau JC, et al. Epidemic influenza and vitamin D. Epidemiol Infect 2006; 134: 1129-40.

14. Schöttker B, Haug U, Schomburg L, et al. Strong associations of 25-hydroxyvitamin D concentrations with all-cause, cardiovascular, cancer, and respiratory disease mortality in a large cohort study. Am J. Clin Nutr 2013; 97: 782-93.

15. Holick MF. Vitamin D: A millenium perspective. J Cell Biochem 2003; 88: 296-307.

16. Holick MF, Chen TC. Vitamin D deficiency: a worldwide problem with health consequences. Am J Clin Nutr 2008; 87: 1080-6.

17.Sağır M, Kaplan M, Tanoğlu A, Demirel F. Relationship between vitamin $\mathrm{D}$ levels and mortality rates of critically ill patients in intensive care unit. Anatolian Curr Med J 2021; 3: 171-5.

18.Lee IM, Shiroma EJ, Lobelo F, Puska P, Blair SN, Katzmarzyk PT. Effect of physical inactivity on major non-communicable diseases worldwide: an analysis of burden of disease and life expectancy. Lancet 2012; 380: 219-29.

19. Okyay R, Koçyiğit B, Gürsoy S. Vitamin D levels in women with fibromyalgia and relationship between pain, tender point count and disease activity. Acta Med Mediterr 2016; 32: 243-47.

20. Masuko K. The multifaceted effects of vitamin D and its potential contribution to rheumatoid arthritis. British Journal of Medicine and Medical Research 2014; 4: 1680-90.

21.Cantorna MT, Zhu Y, Froicu M, Wittke A. Vitamin D status, 1, 25-dihydroxyvitamin D3, and the immune system. Am J Clin Nutr 2004; 80: 1717-20.

22. Commission WMH Report of clustering pneumonia of unknown etiology in Wuhan City (2019-2020).

23. Hong M, Xiong T, Huang J, et al. Association of vitamin D supplementation with respiratory tract infection in infants. Matern Child Nutr 2020; 16: e12987.

24. Kuba K, Imai Y, Penninger JM. Angiotensin-converting enzyme 2 in lung diseases. Curr Opin Pharmacol 2006; 6: 271-76.

25. Ishii K, Takeuchi $\mathrm{H}$, Fukunaga $\mathrm{K}$, et al. Attenuation of lipopolysaccharide-induced acute lung injury after (pro)renin receptor blockade. Exp Lung Res 2015; 41: 199-207.

26. Molloy EJ, Murphy N. Vitamin D, Covid-19 and Children. Ir Med J 2020; 113: 64.

27. Ilie PC, Stefanescu S, Smith L. The role of vitamin D in the prevention of coronavirus disease 2019 infection and mortality. Aging Clin Exp Res 2020; 32: 1195-8.

28. Chowdhury R, Taneja S, Bhandari N, et al. Vitamin-D deficiency predicts infections in young north Indian children: A secondary data analysis. PLoS One 2017; 12: e0170509.

29. Banajeh SM. Nutritional rickets and vitamin D deficiency-association with the outcomes of childhood very severe pneumonia: a prospective cohort study. Pediatr Pulmonol 2009; 44: $1207-15$. 
30. Yao J, Liu L, Chen G, et al. Two severe cases of H7N9 pneumonia patients with immunoneuroendocrine axis dysfunction and vitamin D insufficiency. BMC Infect Dis 2014; 28: 44.

31. Holick MF. Sunlight and vitamin D for bone health and prevention of autoimmune diseases, cancers, and cardiovascular disease. Am J Clin Nutr 2004; 80: 1678-88.

32. Arihiro S, Nakashima A, Matsuoka M, et al. Randomized trial of vitamin D supplementation to prevent seasonal influenza and upper respiratory infection in patients with inflammatory bowel disease. Inflamm Bowel Dis 2019; 25: 1088-95.

33. Urashima M, Segawa T, Okazaki M, et al. Randomized trial of vitamin $\mathrm{D}$ supplementation to prevent seasonal influenza $\mathrm{A}$ in schoolchildren. Am J Clin Nutr 2010; 91: 1255-60.

34. Camargo CA Jr, Ganmaa D, Frazier AL, et al. Randomized trial of vitamin $\mathrm{D}$ supplementation and risk of acute respiratory infection in Mongolia. Pediatrics 2012; 130: 561-7.

35. Uçar F, Taşlıpınar MY, Soydaş AÖ, Özcan N. 25-OH vitamin D levels in patients admitted to Ankara Etlik İhtisas Training and Research Hospital. Eur J Basic Med Sci 2012; 2: 12-5.

36.Erol AM, Çelik C, Hacıoğlu K, et al. The relationship between vitamin D level and lipid profile in patients admitted to Physical Medicine and Rehabilitation outpatient clinic. Ege Med J 2015; 54: 173-6.

37. Silva MC, Furlanetto TW. Does serum 25-hydroxyvitamin D decrease during acute-phase response? A systematic review. Nutr Res 2015; 35 : 91-6.

38. Ebadi M, Montano-Loza AJ. Perspective: improving vitamin D status in the management of COVID-19. Eur J Clin Nutr 2020; 74: 856-9. 